\section{Defense economics: achievements and challenges}

\section{Keith Hartley}

$\mathrm{D}$ efense economics is a relatively new part of the discipline of economics. One of the first specialist contributions in the field was by Hitch and McKean, The Economics of Defense in the Nuclear Age, published in 1960. This article presents an overview of the achievements and challenges for defense economics. The achievements are based on a review of papers published in the research journal Defense and Peace Economics, especially publications and progress since the Tenth Anniversary Issue (2000). The focus is on coverage of topics, including Special Issues. Major gaps in coverage are identified.

The choice of topics for challenges facing defense economics represents a personal view. These include the defense economics problems; U.K. nuclear weapons policy; project case studies based on the example of the Eurofighter Typhoon; the military production function and the role of military outsourcing; and some data problems illustrated with reference to the costs of conflict and the Iraq war.

\section{Achievements: definitions and research coverage}

The definition of defense economics has evolved to reflect new threats and new policy developments. During the Cold War and in its immediate aftermath, defense economics was defined as the economic study of defense, disarmament, conversion, and peace. In the post-Cold War environment, the focus has shifted to the economics of war and peace. Modern definitions embrace the study of wars and conflicts, both conventional and non-conventional. Examples include the economic study of civil wars, revolutions, and terrorism. ${ }^{1}$

Some of the pioneering contributions in the field were made by U.S. economists (although they are less dominant today). These contributions included (1) models of arms races, (2) economic theories of alliances, (3) the demand for military expenditure, (4) defense, growth, and development, (5) procurement and contracting, and (6) the economics of military personnel, especially an all-volunteer force. ${ }^{2}$ On the last topic, it is interesting to compare the U.K. and U.S. experience. The United Kingdom introduced an all-volunteer force earlier than the United States, but compared with America, U.K. economists were not actively involved in the policy debate.

Reflecting the end of the Cold War, globalization, and new security threats, for example in the form of international terrorism, new developments in defense economics include (1) economic studies of disarmament and the peace dividend, especially the novel idea of analyzing disarmament as an investment process; (2) the arms trade; (3) terrorism; (4) the economics of peacekeeping; and (5) the economic study of conflict. Compare market analysis with conflict. Markets are characterized by voluntary trade and exchange, based on the price mechanism, by markets in equilibrium, and by the growth of output (creative power). In complete contrast, conflict uses military force to achieve a re-allocation of resources, markets are in disequilibrium (chaos), conflict destroys markets, and conflict focuses on destructive power rather than creative power (i.e., it involves the destruction of physical and human capital). ${ }^{3}$

The research journal: Defense and Peace Economics

Background

To serve the needs of the defense economics research community, a dedicated specialist research journal was launched in 1990. The journal provides an indicator of the development of defense economics and its establishment as a reputable subdiscipline of economics (cf., health economics). Initially titled Defense Economics, it was at first published four times a year. Supported by an international Editorial Board, joint leadership was provided by a U.K.-based Managing Editor and a North American Editor, the latter reflecting the presence of a substantial number of U.S.based defense economists. In 1995, the journal was renamed Defense and Peace Economics to reflect the post-Cold War security changes and the increasing focus on disarmament, conversion, and peace issues. Publication was increased to six issues per year in 2000, a further reflection of the growing academic interest in the field. In late 2006, the typical lag between acceptance of a paper and its publication was about 12 months.

\section{Features of the journal}

Whilst the journal focuses on economics papers, it readily accepts good quality contributions from related disciplines as well as articles written by policymakers, industrialists, and practitioners. Two distinctive features are its Country Survey Series and its Special Issues. To date, there have been some 20 Country Surveys, each designed to provide data, analysis, and evaluation of a country's defense economy (e.g., data on defense expenditure, armed forces, demand for defense spending, and, if applicable, its defense industrial base). There remains scope for more Country 
Surveys of both major defense spending nations (e.g., the United States) and nations which in defense economics terms are less well-known (e.g., China, India, Iran, Iraq, Pakistan, the new NATO members, and North Korea).

The journal has published numerous Special Issues. These include special, topical, and at the time under-researched themes (e.g., terrorism, arms exports, and defense R\&D), tributes to leading defense economists (e.g., Jack Hirshleifer), and selections of conference papers focusing on a common theme. Special Issues intended to promote defense economics in a specific country (e.g., Canada, Greece, South Africa, Spain, Turkey) have also been published. Each Special Issue requires a Guest Editor who is responsible for the content of the Issue and the quality of the articles. Proposals for Special Issues are made to the Editors who will then commission the Issue, or the Editors might approach someone to take the lead and develop a Special Issue.

\section{The Tenth Anniversary Issue, 2000}

The tenth anniversary of the journal was commemorated with a special Tenth Anniversary Issue. ${ }^{4}$ This contained an article reviewing the coverage of the journal to that date. There were also articles on concepts of defense economics, arms races, conflict and exchange, defense and foreign aid, manpower economics, and disarmament.

This section summarizes the main findings of the review of coverage from 1990 to 2000. The top-10 topics covered were (figures in brackets show the number of articles): (1) defense expenditure studies [29], (2) procurement processes and policies [21], (3) economics of alliances [18], (4) resource conversion from military to civilian applications [17], (5) the defense industries and defense industrial base [16], (6) military manpower [14], (7) country surveys [11], (8) terrorism, guerrilla warfare, and insurgencies [11], (9) defense and growth [9], and (10) public choice and defense [8].

In contrast, areas with relatively little coverage included articles on arms races, the arms trade, disarmament and arms control, the military production function, the nature of defense economics, and defense budgets. In view of their importance and topicality, the small number of articles on arms races and the arms trade was surprising. Other gaps included game theoretic analysis of defense, peace economic studies (including peacekeeping missions, regional arms races, and conflict resolution), contributions from related disciplines, and good quality case studies of defense industries, projects, and of conversion (both successful and unsuccessful).

Progress since 2000

The record of publications since the anniversary issue (i.e., since 2000/1) enables an assessment of the changing trends in defense economics. From 2000/1 to 2006/6, the journal has published 41 issues with 221 articles. Table 1 shows the topics with the greatest coverage over this period. In aggregate, these topics account for 87 percent
Table 1: Coverage from 2000 to 2006
Topics and number of articles

Defense-growth

Conflict

Defense industrial base

Arms races and arms control

Terrorism

Military production function

Defense expenditure

\section{Topics and number of articles}

Peace and peacekeeping $\quad 12$

Debt issues

Defense R\&D

Alliances

Manpower economics

Arms trade

Country surveys of all topics published over the period. Inevitably, there are problems of classification, especially with defense-growth and defense expenditure studies as well as with personnel and military production function articles. Nonetheless, compared with the 1990-2000 period, there are some new topics in the top list. These include conflict, arms races, terrorism, the military production function, peacekeeping, defense R\&D, and the arms trade.

Equally interesting are the topics which have received little coverage. These include European defense policy, disarmament, conversion, security policy, defense budget trade-offs, procurement, regional issues, public choice, and the nature of defense economics.

The list of Special Issues is a further indicator of developments in defense economics. Since 2000, there have been 16 Special Issues reflecting new topics, new themes, conference proceedings, and efforts to promote defense economics in specific countries. Table 2 shows the coverage of Special Issues since the anniversary issue.

Major gaps remain, as before 2000. There is a need for good quality analytical and critical case studies of conflict, defense industries, projects, and conversion (both successful and failed conversions). Examples include the Iraq war and experience with major weapons projects such as aircraft carriers, combat aircraft (e.g., F-22, JSF, Typhoon), and submarines. There is also scope for more articles from policymakers, the armed forces, and from industry.

Other opportunities exist in procurement and contracting, analysis of the efficiency of the armed forces, and the military production function. The history of economic thought in war, defense, and peace is another gap. Finally, globalization issues need to be addressed, embracing global threats, global defense industries, and global military solutions (e.g., peacekeeping and ad hoc military alliance such as "coalitions of the willing”).

Challenges: the defense economics problem and two examples

The defense economics problem is the standard economics problem of choice under 
Table 2: Special issues, 2000 to 2006

Arms exports

South Africa

Defense in Greece and Turkey

Economics of defense: perspectives from Spain

Civil wars

Defense and economic development in the Balkans

Economic analysis for defense decisionmakers

Internal and external threats

Economics of conflict, civil war, and peace: historical perspectives

Symposium on defense economics

Deficit, debt, and defense

Future of the defense firm

Canadian perspectives on defense economics

Defense R\&D

Peacekeeping

Essays in honor of Jack Hirshleifer

uncertainty. It reflects two trends. First, for most nations, defense budgets in real terms have been either broadly constant or falling. Second, input costs for equipment and military personnel have been rising. Unit equipment costs have doubled every decade leading to smaller numbers of equipment ordered from defense industries and smaller numbers for the armed forces (e.g., a long-run downward trend in the numbers of combat aircraft, tanks, and warships in the armed forces). Also, for military personnel, the costs of an all-volunteer force have to rise faster than wage increases in the civilian sector (i.e., to compensate for the net disadvantages of the military employment contract: discipline, mobility, danger, long and unsociable hours on operations, and the probability of injury and death). The result of these trends is the need for difficult defense choices. Whilst higher defense spending will "solve” some of these problems, it shifts the choice problem from defense to social welfare spending and taxation levels (i.e., "guns versus butter" choices).

Interestingly, the end of the Cold War has made no difference to unit cost escalation: it has continued. For example, the U.K. cannot afford a successor to the Typhoon combat aircraft, attack helicopters are becoming unaffordable so that there is a renewed future for main battle tanks, and by the time UAVs are as capable as manned aircraft, they will be equally as expensive and hence just as unaffordable. ${ }^{5}$

A further dimension affects the defense economic problem. Evidence shows that there is a positive relationship between annual defense R\&D spending some 10 to 25 years earlier and military equipment capability (or years of advantage). This relationship is subject to diminishing returns. It shows that the United States is the world leader and that it is some 5 to 6 years ahead of the U.K. and France, some 8 years ahead of Germany, and about 12 years ahead of Sweden. The result is that the U.S. defense industry has an international competitive advantage reflected in its defense export performance. But the U.S. advantage comes at a price. Its lead over the U.K. involves an annual defense R\&D budget which is five times that of Britain. ${ }^{6}$

A variety of responses are available to address the defense economics problem. These include "equal misery," affecting all the armed forces and involving less training, fewer attrition buys, some project cancellations, and delays in delivering new equipment (i.e., shifting new equipment programs to later time-periods). Alternatively, there could be a defense review involving a major shift in a nation's defense commitments (e.g., abandoning some capabilities, or role specialization), or nations could seek to improve efficiency in procurement through competitive purchasing and military outsourcing. For European nations, an EU defense policy is a further option.

Economic theory offers some policy guidelines and principles for formulating defense policy. First, the principle of final outputs requires a focus on the final outputs of defense in terms of peace, security, and protection or, more realistically, in terms of defense capabilities. For example, it might be that a nation's defense budget provides the capability to be involved in a major conflict as part of an international coalition (e.g., the U.K. in Iraq and Afghanistan) or to be involved in, say, three small to medium-scale operations (e.g., peacekeeping). Such an approach shows the limitations of focusing on inputs. Typically, debates about defense policy focus on the implication of budget cuts for the size of the army, navy, and air force (e.g., cuts in the numbers of infantry regiments, tanks, warships, and combat aircraft squadrons). This is the wrong focus. Instead, the key question is what contribution do these inputs of soldiers, warships, and aircraft make to the final outputs of peace and security and what would be the impact of marginal changes in these inputs (e.g., reducing the size of the navy by 5 percent and increasing the size of the army by 5 percent)?

A second economic principle is that of substitution. This recognizes that there are alternative means of achieving protection. For example, there are substitution possibilities between civilians and military personnel, between reserves and regulars, between attack helicopters and tanks, between cruise missiles/UCAVs and manned combat aircraft, between air power and land forces, and between nuclear and conventional forces. Some of these substitution possibilities affect the traditional monopoly property rights of the armed forces. It might mean cruise missiles operated by the army and navy replacing manned combat aircraft operated by the air force.

A third economic principle is that of competition as a mechanism for achieving 
efficiency. Here, opportunities exist for introducing or extending competition to the purchase of defense equipment (e.g., buying from overseas rather than from a national defense industrial base) and to military outsourcing. Typically, the armed forces operate a monopoly of services provided by "in-house” units. Such activities could be opened-up to competition by allowing private firms to bid for this work (e.g., catering, training, transport, managing military bases, and training ranges).

\section{U.K. nuclear weapons policy}

The first specialist defense economics textbook, published in 1960, was entitled The Economics of Defense in the Nuclear Age. ${ }^{7}$ Nearly 50 years later, the U.K. is considering whether to replace its Trident strategic nuclear force. This decision will be controversial, involving political, military, and moral issues. But economics cannot be ignored since costs are involved.

Economic principles such as the principles of final output, substitution, and competition can help focus the questions defense decisionmakers need to answer.

Economists assess a Trident replacement decision by starting with a conceptual framework. Policy options need to be identified, embracing submarine, air, and landbased alternatives for a strategic deterrent (including the option of running-on Trident for longer than its original planned service life). The options then need to be assessed using a costbenefit framework. Costs include acquisition, life-cycle, and disposal costs. Benefits embrace the military effectiveness of the options in relation to the military requirement. There are also wider economic and industrial benefits to be included in the evaluation. These include such factors as security of supply, the retention of industrial capabilities, and the impact on jobs, technology, and any exports.

Opportunity costs cannot be ignored. One estimate suggests replacement costs of $£ 15$-20 billion over 20 years (based on building a new Vanguard/Trident force at 2006 prices), but the estimate might be double that figure or considerably less. No official figures are as yet available. An expenditure of £15-20 billion could be used for alternative defense spending on conventional equipment. For example, $£ 15-20$ billion might buy 30 to 40 Type-45 destroyers, or two aircraft carriers plus their JSF aircraft and helicopters, or 230 to 310 Typhoon combat aircraft. (These are illustrative examples based on acquisition costs only.) Alternatively, there are Trident versus social welfare trade-offs. Alternative civil spending is available in the form of 100 to 130 new hospitals (capital costs only, over 20 years) instead of a Trident replacement.

A Trident replacement also affects the future of the U.K. submarine industrial base (UK SIB). Without a submarine replacement for the U.K.'s nuclear deterrent force, it will be difficult and costly to maintain a UK SIB. But a submarine replacement will require contract negotiations with a U.K. monopoly supplier (viz., BAE Systems) and the associated problems of determining prices and profits on non-competitive contracts and providing efficiency incentives whilst avoiding "excessive” profits. As always, there are no costless options.

Project case studies: Typhoon

Typhoon illustrates the opportunities for in-depth case studies of major equipment projects and for the economic evaluation of such programs. Economic theory suggests guidelines for an efficient defense industrial policy in an alliance and these can be used to assess the efficiency of the Typhoon program. Efficient programs are characterized by gains from trade based on specialization by comparative advantage, by gains from economies of scale and learning, and by reduced duplication of costly $\mathrm{R} \& \mathrm{D}$. Typhoon fails on gains from trade since its work-sharing arrangements are not based on comparative advantage among partner nations. Instead, work is allocated on the basis of juste retour, reflecting the size of national orders and the desire of each nation for a share of the high technology work on the program and for national final assembly lines. However, Typhoon scores more highly on gains from scale and learning through combining all national orders into one large-scale order, but it loses some economies of learning through duplicate final assembly lines (but final assembly amounts to only 3 to 5 percent of production costs). Finally, there are some gains for Typhoon from reduced duplication of costly R\&D programs (e.g., four nations choosing one R\&D program).

The large-scale public expenditure on Typhoon of over $€ 54$ billion (2004 prices for development and production) has attracted considerable public scrutiny by national parliaments. Criticism has also been made of the continued relevance of Typhoon in the new post-Cold War security environment, the high and rising costs of the project, its considerable delays, the inefficiencies of its industrial arrangements, and the bureaucracies of the customer governments. However, there has been little information on the economic benefits of Typhoon. What are its benefits in terms of jobs, technology spin-offs, and balance of payments (exports and import-savings)? Such economic and industrial benefits are part of a complete cost-benefit economic evaluation of Typhoon. ${ }^{8}$

Economic benefits

Typhoon supports about 105,000 jobs directly and indirectly in over 400 European companies. In 2006, these jobs were distributed as follows: Germany and Italy with 20,000 each, Spain with 25,000, and the U.K. with 40,000 jobs. Many of these are highly-skilled and high wage jobs in development, production, and support. Many of Typhoon's labor skills are highly transferable (e.g., to motor car and electronic industries, and to Airbus A380 work).

An impressive list of technology benefits and spin-offs from Typhoon can be 
cited. Examples include carbon-fiber technology, flight control systems, and aeroengine technology. There are spin-offs to civil aircraft, to motor car industries (including Formula 1 racing cars in Italy and the U.K.), and further spin-offs to supply chains (including the application of modern business practices).

Typhoon offers export and import-savings benefits which further contribute to providing jobs and to maintaining the European defense industrial base which represents an alternative source of supply to the United States. In late 2006, Typhoon export orders amounted to 90 aircraft valued at $€ 9.5$ billion. Also, the import-saving contribution of Typhoon was estimated at $€ 33.5$ to $€ 54$ billion (acquisition costs only: the higher estimate assumed that Typhoon was the least-cost solution and the lower estimate assumed a mixed buy of U.S. F-15E and F-18E/F aircraft). On this basis, the total balance of payments contribution of Typhoon is some $€ 43$ to $€ 63.5$ billion.

\section{A critique}

The economic benefits of Typhoon need to be evaluated critically. The opportunity cost question cannot be avoided. Would the resources used on Typhoon make a greater contribution to national output if they were used elsewhere in the economy?

Similarly, examples of technology spin-offs appear impressive but they are qualitative, not quantitative: there are lots of examples and case studies, but little evidence on their valuation. What is the market value of these spin-offs and what is their transmission mechanism? One estimate based on the Netherlands' experience with its planned JSF purchase suggested that Typhoon technology spin-offs might be valued at $€ 7.2$ billion (2004 prices) but this is likely to be a lower-bound estimate. ${ }^{9}$ Some of the mechanisms whereby technology from Typhoon is "spun-out" to other sectors of the economy have been identified. These included labor turnover with skills transferred elsewhere either within a company or to other firms (e.g., the motor car industry in Germany), through staff on Typhoon acting as consultants (e.g., to the Formula 1 racing car industry), through the supply chains, and through links with universities. ${ }^{10}$

A more fundamental critique of the economic benefits of Typhoon concerns their market failure dimension. Do arguments about jobs, technology, and exports reflect genuine market failures justifying state intervention? Is state intervention likely to be worthwhile? And are defense projects, such as Typhoon, the most efficient form of intervention to correct market failures? In relation to jobs and exports, it is likely that labor and foreign exchange markets are working reasonably well, but spin-offs are a beneficial externality suggesting failure in technology (R\&D) markets.

Finally, collaboration inefficiencies on Typhoon cannot be ignored. These embrace development and production and are reflected in the work-share arrangements, the industrial organization, and the customer governments of the partner nations, all of which have led to cost increases and delays. For example, the
Typhoon program lacks a single lead company as prime contractor with management authority and financial responsibility, and also it lacks a single customer. Governments are subject to changing requirements, national agendas, industry lobbying, and different budgetary pressures (national projects are not immune from such features). The Eurofighter company recognizes that about one third of the 54months delay was due to the company and its management organization, with the remainder attributed to the partner governments, their budget problems, and to changes following the end of the Cold War.

The Typhoon program offers some lessons for future collaborations. First, workshares need to be based on efficiency and competitiveness criteria rather than political bargaining and equity among partner nations. Second, collaboration needs a single prime contractor subject to the risks of a fixed price or target cost incentive contract. Despite its recent problems, Airbus is an example of a successful collaboration.

Conclusion: further challenges

Challenges for the armed forces

Just as private industry undertakes continuous change due to changing consumer preferences, new technology, and the emergence of lower cost rivals at home and overseas, the armed forces cannot avoid the need to change. Drivers for change come from budget cuts, new technology, new threats, new conflicts, and sometimes from government through a new, innovative defense minister (e.g., McNamara).

The need for change in the armed forces means that they may have to address radical solutions and depart from traditional ways of doing business. For example, the substitution principle with, say, a greater use of reserve forces and more military outsourcing, has to be addressed in an era of defense budget constraints and a preference for social welfare spending. The search for efficiency improvements in the armed forces is limited by their lack of private market incentives in the form of competition, the profit motive, and the policing role of capital markets (i.e., threats of takeovers and bankruptcy).

\section{Challenges for defense economics}

Based on traditional and new topics, a massive research agenda remains. Traditional areas include the scope for further analytical and empirical work on the military production function and the efficiency with which the armed forces convert inputs into military outputs. Here, there is scope for the international comparison of laborcapital relationships in such forms as the numbers of military personnel per warship, tank unit, and combat aircraft squadron. Military outsourcing also provides a check on the internal efficiency of various activities of the armed forces and questions arise about the optimal extent of such outsourcing (e.g., combat units). 
Data problems remain, but the collection of reliable data provides a public good subject to free-riding, and this is not an attractive route to fast promotion in the economics profession! Two examples illustrate the challenges. First, there is a need for more data on the defense industrial base for each nation in the world. China is an obvious data gap. Also, there is a lack of data on defense R\&D, especially its inputs of scarce scientists and engineers. Second, new studies of the economics of conflict require data on the costs of conflict. Such data are difficult to obtain. There are military costs and civilian costs to be considered. Ideally, data are needed on the planned military costs and final outcomes, including the impact of conflict on all participating nations. Even the apparently simple task of obtaining data on the military costs of the conflict and peacekeeping phases of operations in Afghanistan and Iraq are fraught with difficulties. There remains scope for a proper costing of the conflicts in Iraq and Afghanistan.

\section{Notes}

Keith Hartley directs the Centre for Defence Economics, University of York, York, YO 10 5DD, England and is co-founder and editor of Defense and Peace Economics. He may be reached at kh2@york.ac.uk.

1. For example, Brauer (2003); Barros and Sandler (2003); Hartley (2007); Hegre and Sandler (2002).

2. For example: (1) Richardson (1960); Intriligator and Brito (1989); Schelling (1966); (2) Olson and Zeckhauser (1966); Sandler (1988); (3) R. Smith (1980); (4) Benoit (1973); (5) Peck and Scherer (1962); (6) Hansen and Weisbrod (1967); Oi (1967). A detailed reference list for these pioneering contributions is provided in Sandler and Hartley (1995).

3. For example: (1) Hartley, et al. (1993); (2) Levine, Sen, and Smith (2000); (3) Sandler (1992); (4) Solomon and Berkok (2006); (5) Hartley and Sandler (2003). For an up-to-date coverage, also see Sandler and Hartley (2007).

4. See Hartley and Sandler (2000).

5. Pugh (2007).

6. Middleton, et al. (2006).

7. Hitch and McKean (1960).

8. See Hartley (2006).
9. Hartley (2006, pp. 17-18).

10. Hartley (2006, p. 17).

References

Brauer, J., ed. 2003. Economics of Conflict, War, and Peace in Historical Perspective. Defense and Peace Economics. Special Issue. Vol. 14, No. 3.

Barros, C.P. and T. Sandler, eds. 2003. Internal and External Threats: Defense Economic Analysis. Defense and Peace Economics. Special Issue. Vol. 14, No. 6.

Hartley, K., et al. 1993. Economic Aspects of Disarmament: Disarmament as an Investment Process. New York: UNIDIR.

Hartley, K. and T. Sandler, eds. 2000. Special Anniversary Issue of Defense and Peace Economics. Defense and Peace Economics. Vol. 11, No. 1.

Hartley, K. and T. Sandler, eds. 2003. The Economics of Conflict, vols. 1-3. The International Library of Critical Writings in Economics 168. Cheltenham, UK: Elgar.

Hartley, K. 2006. “The Industrial and Economic Benefits of Eurofighter Typhoon.” Report for Eurofighter. Hallbergmoos: Germany.

Hartley, K. 2007. "Defense Economics," in S. Durlauf and L. Blume, eds. New Palgrave Dictionary of Economics. 2nd edition. London: Macmillan (forthcoming).

Hegre, H. and T. Sandler, eds. 2002. Economic Analysis of Civil Wars. Defense and Peace Economics. Special Issue. Vol. 13, No. 6.

Hitch, C.J. and R. McKean. 1960. The Economics of Defense in the Nuclear Age. Cambridge, MA: Harvard University Press.

Levine, P., S. Sen, and R. Smith, eds. 2000. Arms Exports, Controls and Production. Defense and Peace Economics. Special Issue. Vol. 11, No. 5.

Middleton, A. and S. Bowns, with K. Hartley and J. Reid. 2006. "The Effect of Defense R\&D on Military Equipment Quality.” Defense and Peace Economics, Vol. 17, No. 2, pp. 117-139.

Pugh, P. 2007. "Retrospect and Prospect: Trends in Cost and their Implications for UK Aerospace.” Defense and Peace Economics (forthcoming).

Sandler, T., ed. 1992. Terrorism, Guerrilla Warfare, and Insurrections. Defense Economics. Special Issue. Vol. 3, No. 4.

Sandler, T. and K. Hartley. 1995. The Economics of Defense. Cambridge Surveys of Economic Literature. Cambridge, UK: Cambridge University Press.

Sandler, T. and K. Hartley, eds. 2007. Handbook of Defense Economics, vol. 2. Amsterdam: Elsevier.

Solomon, B. and U.G. Berkok, eds. 2006. Canadian Perspectives on Peacekeeping. Defense and Peace Economics. Special Issue. Vol. 17, No. 5. 